\title{
Portfolio As A Teaching Method: A Capstone Project To Promote Recognition Of Professional Growth
}

Robert Wolffe, Ed.D., Bradley University, USA

Heljä Antola Crowe, Ph.D., Bradley University, USA

Wayne Evens, Ph.D., Bradley University, USA

Kelly McConnaughay, Ph.D., Bradley University, USA

\begin{abstract}
A reflective portfolio as a capstone assignment was selected to accomplish recognition by teachers completing a science, technology, mathematics, engineering master's program for elementary teachers about their professional and personal changes and to provide program evaluators additional qualitative data regarding attainment of program goals. As the teachers in the program $(N=20)$ neared the completion of the program, they were required to take a comprehensive look at their experience. This data-driven, reflective portfolio experience showed that the process clarified teachers' learning in strategies to improve student learning, importance of reflective practice, their role as a teacher leader, dedication to life-long learning and confidence in being an effective professional educator.
\end{abstract}

Keywords: Reflective Portfolio; Capstone Project; Promote Recognition of Professional Growth

\section{INTRODUCTION}

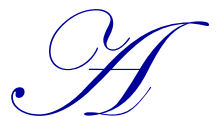

powerful capstone assignment was selected to accomplish two goals in Bradley University's Professional Master's degree program in Math and Science for Elementary teachers. As the teachers in the program $(\mathrm{N}=20)$ neared the completion of the program, they were required to take a comprehensive look at their experience. This was done through a portfolio experience to promote a thorough, datadriven, reflective voyage through their program to enhance their knowledge, skills and attitudes as professional educators. The portfolio served two distinct, intertwined purposes:

- $\quad$ To promote recognition by teachers completing the program about their professional and personal changes experienced and

- $\quad$ To provide program evaluators additional qualitative data regarding attainment of program goals.

Reflective practice in teaching deepens teachers' understanding of the successes of their decision-making in relation to teaching strategies chosen and their ability to design and implement effective learning experiences. Teachers analyzed their growth in their knowledge of science, math and technology and its applications to their own classrooms. Reflections also included scrutiny of growth related to leadership skills and student learning gains.

After completing professional growth sections of the portfolio, they looked back at their entire experience as framed by professional dispositions. It is their writing in this final section of their portfolios that served as the basis of our analysis. 


\section{ANALYSIS}

Each submission was analyzed to determine themes apparent in their responses. As the themes emerged, the teachers' reflections were reread to both refine the attributes of the themes and to confirm (Trochim, 2006) the assignment of theme codes to the text. This analysis demonstrated numerous changes in teachers' knowledge and skills. Prominent in the emerging themes were:

- $\quad$ Strategies to improve student learning

- Importance of reflective practice

- $\quad$ Role as a teacher leader

- $\quad$ Dedication to life-long learning

- $\quad$ Confidence in being an effective professional educator

It is significant that these areas were aspects of responses by multiple teachers completing the program. They reflect positively on attainment of program goals grounded in areas of professionalism linked to teacher quality research. A brief summary of narratives and the importance of the teachers' statements follow.

\section{SUMMARY OF EFFECTS}

\section{Strategies to Improve Student Learning}

When the cohort members entered the program, most stated as a reason for applying a desire to become a better teacher. In their capstone reflections they wrote at length how they improved in their ability to offer their students an increased repertoire of pedagogical approaches. This included multiple comments about possessing improved ways to provide hands-on instruction, to design lessons that promote inquiry and to differentiate instruction. There was a strongly held belief that the growth in knowledge was benefitting their students now and a parallel belief that this was just a start. One teacher wrote,

Our generation has taken part in some of the most rapid changes in technology, travel, and philosophy. Who knows what is in store for the next generation that we are currently teaching. We need to be willing to try new ideas that will work best for them as they begin their education. We need to be open to all the new ideas bombarding us so that we can try them to see what works best for our style of teaching and what works best for their style of learning.

In many reflections related to improving student learning, candidates have become more aware of the need for constructivist approaches to teaching (Fosnot \& Stewart Perry, 2005). They see the need for learners to connect with their prior knowledge but can flexibly use knowledge and respond pedagogically to the differences between learners and their needs. Marzano (1998) found that pedagogies that include metalearning, such as setting goals, or monitoring progress, are more effective in improving student learning outcomes strategies than only engaging learners at the level of presenting information for understanding and use. Being a more aware reflective practitioner also helps teachers to model metalearning with their students as a reflective practitioner (Schön, 1983).

\section{Importance of Reflective Practice}

While candidates learned to cultivate the capacity to reflect in action (while doing something), the portfolio work mainly looks at reflection on action (after accomplishing something). Schön (1983) suggests that the capacity to reflect on action is a defining characteristic of teachers' professional practice. Comments related to how participation in the program motivated reflective practices came in many forms:

- $\quad$ Making the change from student to teacher provided an opportunity for tremendous growth as I was forced to put my ideas and theoretical knowledge to the test.

- $\quad$ Reflecting on my lessons will also help me continue to learn and grow as a teacher.

- $\quad$ I find that I have continual reflection of my roles and practices as a professional whether it is for my classroom alone or what will be best for the greater cause of many. 
As teachers reflect they are much more aware than in the beginning of the habits they use in perceiving, inquiring as they internalize learning (Maudsley, 1979). In being a more aware reflective practitioner, teachers practice many personal meta-learning approaches including different ways of observing, reflection, self-talk, and collegiality (Cross, 2006).

\section{Role as a Teacher Leader}

Teachers expressed a newly found understanding of the importance of leadership, which has translated to more involvement as a teacher leader.

Prior to the program, I did not see myself as a teacher leader. In fact, I shied away from any opportunity that was presented to me. The administrators in my building often said that I carried many leadership qualities and urged me to become more active in taking a leadership role. My personal thoughts were that I need to only focus on my students and what went on in my classroom. As the years have passed, I have seen the value of teacher leaders.

She continues, as did many of the cohort members, by writing about seeking out leadership opportunities and having an increased desire to share both her new found expertise and the results of her critical thinking processes. Awakening to a new possibility of being a teacher leader was seen in the portfolio process. Siitonen and Robinson (1998) point out that teacher leaders utilize empowering practices in their work in the classroom and with their colleagues.

\section{Dedication to Life-long Learning}

The candidates' responses included the concept of continuing growth through continuing consumption of research and internet information, attending conferences and other professional development opportunities and a general desire to continue to change.

- I will continue to attend professional development classes....

- When reflecting on my teaching during this process, life-long learning has been a reoccurring theme. I have set plans for myself that can be overviewed in actions....

- It takes hard work, determination, time, effort, and drive to become an excellent teacher. I am not sure if an excellent teacher ever deems themsel(f) as one since it's a never-ending climb due to the fact that time creates never-ending changes to endeavor. All I can hope is that I am on my way to becoming and excellent teacher someday.

Concepts of life-long learning relate to awareness and the ability to take control of one's own learning (Biggs, 1985). Similar to growing awareness of reflective practice and teacher leadership, life-long learning is a realization of the benefits of the continuity in one's own growth and professional development.

\section{Confidence in being an Effective Professional Educator}

The educators involved in planning this program were convinced from both research and professional experience that attitudes of the cohort members were critical. The fact that a thread related to strengthened confidence emerged from analyzing the narratives is viewed as an important positive effect of program participation. Aspects of this enhanced confidence are seen in the four themes briefly discussed above. The overall effect is captured in this comment:

Overall, this program has allowed me to grow in many new directions that I am amazed. I guess we all have these little talents and resources hidden inside us that we are too afraid to bring out because we don't think ours are good enough. This has taught me to speak up more and question. I do a disservice to myself and my students when I am not more assertive.

The productive effects of the program reflect an expansive sense of the positivity (Frederickson, 2010) and resiliency (Siebert, 2005, Benard, 2004) that build on and further the desire to grow as an effective professional educator. 


\section{CONCLUSION}

The process of developing a portfolio as a capstone experience provided powerfully rich data that assessed candidates' progress attainment of program goals while simultaneously giving the teachers in the cohort a more comprehensive, deeper appreciation of their own growth. A careful review of the responses did provide a more indepth view of the changes experienced by the teachers completing the program. It also shows that for them to scrutinize their analysis of self-growth as the basis for looking at changes in their professional dispositions provided a strong foundation for this reflective process

\section{AUTHORS' INFORMATION}

Robert Wolffe is a Professor of education in the Department of Teacher Education at Bradley University. Besides teaching a variety of teacher preparation courses, e is a site coordinator for professional development schools and is actively involved in teacher education accreditation. His current research interests are focused primarily on factors that enhance the effectiveness of STEM education programs. He co-directs STEM education grant programs and is the outside evaluator or a project in this field. E-mail: rjwolffe@bradley.edu (Corresponding author)

Heljä Antola Crowe, a Professor in Teacher Education at Bradley University in Peoria, Illinois, has her Ph.D. in Curriculum and Instruction from the University of Mississippi, M.A in Educational Administration from the University of Jyväskylä, Finland. She is the author of research and pedagogical publications on empowerment, curriculum, wellbeing and the workplace including a book entitled: The ethnography of Empowerment: The transformative power of classroom interaction. She has conducted hundreds of refereed and invited presentations and workshops nationally and internationally on learner empowerment, teaching and learning. E-mail: helja@fsmail.bradley.edu

Wayne Evens is an Associate Professor of Social Work and the Director of the Social work program at Bradley University. His Ph.D. is from University of Iowa. His recent publications relate to experiential learning, aging populations, feminist empowerment, and child abuse prevention. He has conducted multiple program evaluations including Professional Master's degree programs in STEM-areas.

Kelly McConnaughay, Professor of Biology, is the Associate Dean of the College of Liberal Arts and Sciences and Co-Director of the STEM Education Center at Bradley University. Since earning her PhD from Harvard University in 1990, she has pursued research interests related to plant ecology and factors influencing learning in STEM fields.

\section{REFERENCES}

1. $\quad$ Benard, B. (2004) Resiliency. What we have learned. San Francisco: West Ed.

2. Biggs, J. B. (1985). The role of meta-learning in study process. British Journal of Educational Psychology, $55,185-212$

3. Cross, J. (2006). Informal learning. Rediscovering the natural pathways that inspire innovation and performance. Hoboken , N.J.: Wiley.

4. Fosnot, T. C. \& Stewart Perry, R. (2005). Constructivism: a psychological theory of learning. In Fosnot (Ed.) Constructivism. Theory, perspectives, and practices. New York: Teachers College Press.

5. Hattie, J., Biggs, J., and Purdie, N. (1996). Effects of Learning Skills Interventions on Student Learning: A Meta-analysis. Review of Educational Research, 66, 99-136.

6. Marzano, Robert J. (1998). A Theory-Based Meta-Analysis of Research on Instruction. Mid-continent Aurora, Colorado: Regional Educational Laboratory. Retrieved May 2, 2000 from http://www.mcrel.org/PDF/Instruction/5982RR InstructionMeta_Analysis.pdf

7. Maudsley, D.B. (1979). A theory of meta-learning and principles of facilitation. Toronto, Quebec: University of Toronto.

8. Schön, D. (1983) The Reflective Practitioner, New York: Basic Books

9. Siebert, A. (2005). The resiliency advantage. San Francisco: Burrett-Koehler Publishers. 
10. Siitonen, J. \& Robinson, H. (1998). Empowerment: Links to teachers' professional growth. In Erkkilä, R., Willman, A \& Syrjälä, L. (Eds.) Promoting teachers 'propersonal and professional growth. University of Oulu. Department of teacher education. Acta Universitatis Ouluensis E 32:165-191.

11. Trochim, W. M. K. (2006). Qualitative Validity. Retrieved August 10, 2012, from http://www.socialresearchmethods.net/kb/qualval.php 
NOTES 